\section{Growth and Yield of Young 'Valencia' Sweet Orange Trees Treated with Insecticides}

\author{
Charles A. Powell ${ }^{1}$, Mark A. Ritenour, and Robert C. Bullock \\ Indian River Research and Education Center, Institute of Food and \\ Agricultural Sciences, University of Florida, 2199 South Rock Road, Fort \\ Pierce, FL 34945-3138
}

Additional index words. Admire, imidacloprid, Temik

\begin{abstract}
The trunk diameter of 'Valencia' sweet orange trees tested with seven insect control strategies was measured annually for the first 5 years after planting. Yield data (marketable fruit per tree) were collected after the fourth and fifth years. The insect control treatments were Admire (imidacloprid) applied at 12, 6, 3, or 2-month intervals; Temik (aldicarb) applied annually; Meta-Systox-R (oxydemeton-methyl) applied annually; or no insect control. Trunk diameter was significantly increased by Temik treatment at 1 and 2 years after planting. Six annual applications of Admire (at 2-month intervals) significantly increased trunk diameter 2 years after planting. None of the other treatments affected trunk diameters compared with the control. There were no trunk diameter differences among treatments at 3, 4, or 5 years after planting. Both Temik applied annually and Admire applied every other month or every 3 months significantly increased yield.
\end{abstract}

The use of insecticides in Florida citrus groves has increased significantly in the last several years, largely as a result of the introduction of exotic insect pests that vector recently introduced citrus pathogens. Examples of these are the brown citrus aphid (Toxoptera citricida Kirkaldy) that transmits citrus tristeza virus (Roistacher and Bar-Joseph, 1987), the Asian citrus psyllid (Diaphorina citri Kuwayama) that transmits Candidatus Liberibacter asiaticas and C. L. americanum, causal agents of the huanglongbing (citrus greening) disease (Garnier and Bové, 1978), and the citrus leafminer (Phyllocnistis citrella Stainton), which may predispose trees to Xanthomonas axonopodis Starr, and Garces emend. Vauterin et al., pr. citri, the causal agent of citrus canker (Hill, 1918). Two of the most commonly used insecticides on young trees are Temik (aldicarb) and Admire (imidacloprid). Both Temik (Bullock, 1989; French and Timmer, 1979) and Admire (Powell et al., 2006, 2007) have been shown to control arthropods in citrus.

In addition to controlling certain arthropods (especially mites), Temik has been reported to enhance productivity of mature citrus trees (Knapp et al., 1982; Wheaton et al., 1985) and growth of young Hamlin orange trees (Bullock and Pelosi, 1992). In this study, we investigated the effect of several insecticide treatments, including Temik, Admire, and Meta-Systox-R, on growth and

Received for publication 19 Nov. 2008. Accepted for publication 2 Mar. 2009.

${ }^{1}$ To whom reprint requests should be addressed; e-mail CAPowell@ufl.edu.

\section{Materials and Methods}

The experimental area consisted of 294 'Valencia' sweet orange [Citrus sinensis (L.) Osbeck] trees grafted on sour orange rootstock (C. aurantium L.) at the Indian River Research and Education Center, Fort Pierce, FL. The trees were planted in single beds (rows) with $9.2 \mathrm{~m}$ between rows and the between-tree spacing was $4.5 \mathrm{~m}$. All trees were subject to normal grove management practices, including microsprinkler irrigation, fertilization, and micronutrient sprays.

The experiment was a randomized complete block design with each of six rows serving as a block (replication). There were seven treatments in each of the six blocks with seven trees per experimental unit (plot). There were two border trees at the end of over a 5 -year period. ${ }^{z}$ each row and two between each plot within a row. The treatments were an annual application of Temik (Bayer Cropscience, Research Triangle Park, NC) (8.5 g/a.i. per tree incorporated into the soil); an annual application of Meta-Systox-R (Gowan Co., Yuma, AZ) (trunk drenched, $0.62 \mathrm{~mL} \cdot \mathrm{L}^{-1} /$ tree); soil drenches with imidacloprid [1-(\{6-chloro3-pyridinyl $\}$ methyl)-N-nitro-2-imidazolidinimine] (Admire) (Bayer, Vero Beach, FL) at $1920 \mathrm{mg}$ a.i./plant applied at 2-, 3-, 6-, or 12-month intervals starting in April of each year; and no insecticide application. Temik was applied the last week of April, and the Meta-Systox-R was applied in the spring between 19 Apr. and 22 May. The amount of insecticide used was based on manufacturers' recommendations.

Every June for 6 years, including the time of planting, the trunk diameter of each tree (seven trees for each of the seven treatments in each of six blocks) was measured $10 \mathrm{~cm}$ above the bud union using a caliper. During March, 4 and 5 years after planting, the fruit was harvested and the number of marketable fruit per tree was recorded. Trunk diameter and yield were subjected to a combined analysis using the SAS software program (SAS Institute, Cary, NC). A split-block experimental design was used with years as the main block and treatments as the split block. Main treatment effects means that had a significant F-test were separated by Duncan's multiple range test, 5\% level.

\section{Results}

Although trunk diameter and yield had a significant differential response between treatments and years, the interaction accounted for less than $5 \%$ of the total variation. Therefore, the main effects of treatment for trunk diameter and yield were reported. The first hypothesis tested was that certain insecticides could increase growth of young citrus trees. The results (Table 1) show that an annual application of Temik increased growth (as measured by trunk diameter) of 'Valencia' sweet orange plants on sour orange rootstock during the first and second year after planting, and application of Admire every 2 months increased growth

Table 1. Growth response (trunk diameter) of 'Valencia' orange trees to various insecticide treatments

\begin{tabular}{|c|c|c|c|c|c|c|}
\hline \multirow{2}{*}{$\begin{array}{l}\text { Insecticide } \\
\text { treatment }^{\mathrm{x}}\end{array}$} & \multicolumn{6}{|c|}{ Tree age (years) } \\
\hline & 0 & 1 & 2 & 3 & 4 & 5 \\
\hline$\overline{\text { Admire } 1 \times}$ & 25.96 & $37.91 \mathrm{a}$ & $49.90 \mathrm{a}$ & 59.93 & 75.67 & 76.92 \\
\hline Admire $2 x$ & 25.93 & $37.66 \mathrm{a}$ & $49.33 \mathrm{a}$ & 61.27 & 73.70 & 76.61 \\
\hline Admire $4 \times$ & 28.18 & $37.86 \mathrm{a}$ & $51.10 \mathrm{a}$ & 61.48 & 71.52 & 74.56 \\
\hline Admire $6 \times$ & 27.04 & $39.62 \mathrm{a}$ & $57.17 \mathrm{~b}$ & 69.30 & 83.45 & 88.06 \\
\hline Temik & 27.53 & $44.42 \mathrm{~b}$ & $56.85 \mathrm{~b}$ & 69.13 & 82.10 & 87.22 \\
\hline Meta-Systox-R & 26.78 & $36.89 \mathrm{a}$ & $48.20 \mathrm{a}$ & 57.13 & 68.72 & 69.82 \\
\hline Control & 24.94 & $37.09 \mathrm{a}$ & $50.27 \mathrm{a}$ & 62.32 & 73.65 & 76.57 \\
\hline
\end{tabular}

zThe trunk diameter (mm) means were determined from six replications. Numbers in a column followed by different letters are significantly different (5\% level) by Duncan's multiple range test.

${ }^{y}$ Age of the trees (years) after planting. The 0 column is the diameter at planting.

${ }^{\mathrm{x}}$ Admire $1 \times=$ imidacloprid applied annually; Admire $2 \times=$ imidacloprid applied every 6 months; Admire $4 \times=$ imidacloprid applied every 3 months; Admire $6 \times=$ imidacloprid applied every 2 months; Temik = applied annually; Meta-Systox-R = applied annually; Control = no insecticide applied. 
during the second year after planting. Neither Meta-Systox-R nor less frequent Admire application increased tree growth. None of the insecticides tested increased growth in trees older than 2 years.

The second hypothesis tested was that certain insecticide applications could increase young tree yield. The results (Table 2) show that either an annual application of Temik or application of Admire every 2 months increased the yield of 'Valencia' sweet orange on sour orange rootstock trees 4 and 5 years after planting. None of the other insecticide treatments affected yield compared with the control, untreated trees.

Table 2. Yield of 'Valencia' orange trees in response to various insecticide treatments. ${ }^{2}$

\begin{tabular}{|c|c|c|}
\hline \multirow{2}{*}{$\begin{array}{l}\text { Insecticide } \\
\text { treatment }^{\mathrm{y}}\end{array}$} & \multicolumn{2}{|c|}{ Tree age (years) } \\
\hline & 4 & 5 \\
\hline$\overline{\text { Admire } 1 \times}$ & $50.3 \mathrm{bc}$ & $77.5 \mathrm{bc}$ \\
\hline Admire $2 \times$ & $47.9 \mathrm{bc}$ & $69.8 \mathrm{bc}$ \\
\hline Admire $4 \times$ & $74.4 \mathrm{ab}$ & $97.1 \mathrm{ab}$ \\
\hline Admire $6 \times$ & $82.8 \mathrm{a}$ & $122.9 \mathrm{a}$ \\
\hline Temik & $98.0 \mathrm{a}$ & $128.8 \mathrm{a}$ \\
\hline Meta-Systox-R & $20.6 \mathrm{c}$ & $34.5 \mathrm{c}$ \\
\hline Control & $37.2 \mathrm{bc}$ & $56.3 \mathrm{bc}$ \\
\hline
\end{tabular}

${ }^{\mathrm{z}}$ Mean number of marketable fruit/tree. The means were determined from six replications. Numbers in a column followed by different letters are significantly different $(5 \%)$ by Duncan's multiple range test.

${ }^{y}$ Admire $1 \times=$ imidacloprid applied annually; Admire $2 x=$ imidacloprid applied every 6 months; Admire $4 x=$ imidacloprid applied every 3 months; Admire $6 x=$ imidacloprid applied every 2 months; Temik = applied annually; Meta-Systox$\mathrm{R}=$ applied annually; Control $=$ no insecticide applied.

\section{Discussion}

Two of the insecticides tested (Temik and Admire) have been shown to reduce insect populations in citrus (Bullock, 1989; Powell et al., 2006), although Temik has not always been effective (Powell et al., 2006). Temik has also been shown to enhance productivity of mature citrus trees (Wheaton et al., 1985). We have now shown that both Temik and Admire can increase growth of citrus trees during the second growing season. Although this effect did not last beyond the second year, it translated into increased yields 4 and 5 years after planting. This again confirms the importance of early growth of trees and the resulting increase in yield in subsequent years. Thus, treating young citrus trees with Temik or Admire may increase growth and yield while also insect controlling insects. Whether the increase is a direct result of reduced insect feeding or a physiological effect is unknown. Many Florida growers currently use Temik and/or several treatments with Admire on young citrus trees as part of an asian citrus psyllid control strategy. The increased growth and yield should help offset the cost of psyllid control.

The data reported here are for one citrus variety on a single rootstock in one soil type. Thus, whether application of Temik and/or Admire universally to young citrus is a costeffective management practice awaits further field trials.

\section{Literature Cited}

Bullock, R.C. 1989. Split aldicarb application for pest suppression on navel orange trees in Florida. Proc. Fla. St. Hort. Soc. 102:41 43.

Bullock, R.C. and R.R. Pelosi. 1992. Influence of Temik aldicarb soil treatments on growth of newly-planted 'Hamlin' orange trees. Proc. Intl. Soc. Citriculture 3:991-994.

French, J.V. and L.W. Timmer. 1979. Control of rust mite and reduction of citrus nematode population on Texas orange with Temik. J. Rio Grande Valley Hort. Soc. 33:63-70.

Garnier, M. and J.M. Bové. 1978. The organism associated with citrus greening disease is probably a member of the Schizomycetes. Zentralblatt für Bakteriologie Parasitenkunde Infektionskranheiten und Hygiene Reiha A 241:221-222.

Hill, G.F. 1918. History of citrus canker in the Northern Territory (with notes of its occurrence elsewhere). Northern Territory Australia Bulletin 18:1-8.

Knapp, J.L., T.R. Fasulo, D.P.H. Tucker, and R.P. Muraro. 1982. Comparison of yield, quality, and dollar returns of fruit produced on Temik and non-Temik treated citrus trees. Proc. Fla. St. Hort. Soc. 95:56-60.

Powell, C.A., M.S. Burton, R.R. Pelosi, P.A Rundell, M.A. Ritenour, and R.C. Bullock. 2006. Six-year evaluation of brown citrus and spirea aphid populations in a citrus grove and the effects of insecticides on these populations. HortScience 41:688-690.

Powell, C.A., M.S. Burton, R.R. Pelosi, P.A Rundell, M.A. Ritenour, and R.C. Bullock. 2007. Seasonal abundance and insecticidal control of citrus leafminer in a citrus orchard. HortScience 42:1636-1638.

Roistacher, C.N. and M. Bar-Joseph. 1987. Aphid transmission of citrus tristeza virus: A review. Phytophylatica 19:163-167.

Wheaton, T.A., C.C. Childers, L.W. Timmer, L.W Duncan, and S. Nikdel. 1985. Effects of aldicarb on yield, fruit quality, and tree condition of Florida citrus. Proc. Fla. St. Hort. Soc. 98:6-10. 